\title{
Vitamin-Humic-Algal Root Biostimulant Increases Yield of Green Bean
}

\author{
Ricardo O. Russo and Graeme P. Berlyn \\ Yale University, School of Forestry and Environmental Studies, New \\ Haven, CT 06511
}

Additional index words. biostimulants, humic acid, ascorbic acid, marine algae

Over the past decade there has been a notable increase of research on the use of naturally derived or organic materials in agriculture (Poincelot, 1986; Russo and Berlyn, 1990). Some of these are biostimulants, i.e., nonnutritional products that may reduce fertilizer use and increase yield and resistance to water and temperature stresses. Among the materials that stimulate plant growth in relatively small amounts (Aitken et al., 1964; Berlyn and Russo, 1990; Kinnersley et al., 1989; Senn, 1987; Senn and Kingman, 1973) are humic acids, marine algae, polymers of lactic acid, B vitamins, and ascorbic acid. Under certain conditions, biostimulants work well (Russo and Berlyn, 1990) and suggest possible uses in horticulture.

We tested "Roots" (Lisa Products Corp., New Haven, Conn.), a proprietary mixture of humic acids, marine algae extracts, thiamine, and ascorbic acid. The objective of this study was to assess the effectiveness of this organic biostimulant $(\mathrm{OB})$ on pod production of green beans (Phaseolus vulgaris L.).

Seeds of beans cv. Bush Blue Lake 274 (Agway Inc., Syracuse, N.Y.) were sown and germinated in trays filled with vermiculite. In test A, the first set of 120 seedlings was transplanted, one seedling per pot, to 2.8-liter pots that contained a 1 potting soil (Agway) : 1 vermiculite (v/v) mix. The statistical design was a completely randomized factorial (Statview II, Abacus Concepts,

Received for publication 29 Apr. 1991. Accepted for publication 11 Mar. 1992. This research was funded in part by LISA Products Corp., New Haven, Conn. The cost of publishing this paper was defrayed in part by the payment of page charges. Under postal regulations, this paper therefore must be hereby marked advertisement solely to indicate this fact.

Berkeley, Calif.) The seedlings were grown in three treatments of 40 plants each to evaluate Roots: 1) 0\% (control), $200 \mathrm{ml}$ tap water/ plant when others were treated with $\mathrm{OB} ; 2$ ) $1 \%$, two applications of $200 \mathrm{ml}$ to each plant (at transplanting and on day 26 after transplanting as a soil drench), and 3) 3\%, two applications of $200 \mathrm{ml}$ to each plant on the same dates as in 2) above. In test B, a second set of 120 seedlings was transplanted and grown in two treatment groups of 60 plants each to further test the effectiveness of the $\mathrm{OB}$ at $1 \%$ : 1) control, $100 \mathrm{ml}$ tap water/plant when others were treated with $\mathrm{OB}$; and 2) three applications of $\mathrm{OB}$ at $100 \mathrm{ml}$ to each plant (at transplanting and on days 26 and 45 after transplanting). An analysis of the medium by the Morgan method (Lunt et al., 1950) before any treatment showed the mix was slightly acidic ( $\mathrm{pH}$ 6.4), was mediumlow in nitrate nitrogen $(<4 \mathrm{ppm})$, low in ammonium nitrogen $(<12 \mathrm{ppm})$, medium in $\mathrm{P}(<100 \mathrm{ppm})$, high in $\mathrm{Ca}(>1500 \mathrm{ppm})$, and high in $\mathrm{Mg}(>100 \mathrm{ppm})$. Temperature in the greenhouse was always between 15

Table 1. Pod production of green beans treated with organic biostimulant (OB) at $0 \%, 1 \%$, or $3 \%$ (test A) and at $0 \%$ or $1 \%$ (test B). ${ }^{2}$

\begin{tabular}{lll}
\hline \hline $\begin{array}{l}\text { OB concn } \\
(\%)\end{array}$ & $\begin{array}{c}\text { Mean pod } \\
\text { fresh wt }\end{array}$ & \\
(g/plant) & SE \\
\hline
\end{tabular}

Test $A(n=40)$

$\begin{array}{lll}0 & 33.7 \mathrm{a} & 1.1 \\ 1 & 38.4 \mathrm{~b} & 1.4 \\ 3 & 39.1 \mathrm{~b} & 1.2\end{array}$

Test $B(n=60)$

$\begin{array}{lll}0 & 30.1 \mathrm{a} & 1.1 \\ 1 & 35.6 \mathrm{~b} & 0.9\end{array}$

${ }^{2}$ Mean separation by Fisher's protected LSD, $P=$ $0.05, \mathrm{SE}=$ standard error of the mean. and 30C. Relative humidity was not controlled, and it ranged from $70 \%$ to $100 \%$. Pollutants were not filtered out. Plants were fertilized once with $150 \mathrm{mg}$ N/liter (15N13P-12.5K, Stem's Miracle-Gro Products, Port Washington, N.Y.) 2 weeks after transplanting in both tests.

In test $\mathrm{A}$, pods were harvested 85 days after sowing and 59 days tier transplanting; in test B they were harvested 64 days after sowing and 56 days after transplanting. Pod maturity was gauged subjectively on the basis of experience and pod physical properties. Pod fresh and dry weights per plant were determined. Water content (WC) was determined by using the formula: $\mathrm{WC}=(\mathrm{Wf}-$ $\mathrm{Wd} / \mathrm{Wf} \times 100$; where $\mathrm{Wf}$ is fresh weight and Wd is dry weight. Analysis of variance was performed on pod fresh weights.

The fresh weights of the pods of all biostimulant-treated groups were significantly higher than those of the control $(P<0.05)$. In test $A$, the values were $14 \%$ and $16 \%$ over the control, respectively, and in the validation test (test B), fresh weight for $\mathrm{OB}$ at $1 \%$ was $18 \%$ higher than that of the control (Table 1). The fresh weights were similar for $\mathrm{OB}$ at $1 \%$ and $3 \%$ in test A (Table 1). No vegetative growth differences were observed in these experiments, and pod water content (mean 92\%) was similar for all treatments.

\section{Literature Cited}

Aitken, J.B., B. Acock, and T.L. Senn. 1964. The characteristics of humic acids derived from leonardite. South Carolina Agr. Expt. Sta., Clemson Univ., Tech. Bul. 1015.

Berlyn, G.P. and R.O. Russo. 1990. The use of organic biostimulants to promote root growth. Belowground Ecology 2:12-13.

Kinnersley, A.M., T.C. Scott III, J.H. Yopp, and G.H. Whitten. 1989. Promotion of plant growth by polymers of lactic acid. Plant Growth Regulat. 9(2):137-146.

Lunt, H.A., C.L.W. Swanson, and H.G.M. Jacobson. 1950. The Morgan soil testing system. Connecticut Agr. Expt. Sta., New Haven.

Poincelot, R.P. 1986. Toward a more sustainable agriculture. AVI, Westport, Conn.

Russo, R.O. and G.P. Berlyn. 1990. The use of organic biostimulants to help low input sustainable agriculture. J. Sustainable Agr. 1(2):1942.

Senn, T.L. 1987. Seaweed and plant growth. T.L. Senn, Pub., Clemson, S.C.

Senn, T.L. and A.R. Kingman. 1973. A review of humus and humic acids. The South Carolina Agr. Expt. Sta., Clemson Univ., Res Series. no. 143. 